\title{
Keeping kosher or not keeping kosher in contemporary Denmark
}

Johan Fischer

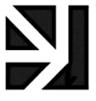

VERTAISARVIOITU

KOLLEGIALT GRANSKAD

PEER-REVIEWED

www.tsv.fi/tunnus

DOI: https://doi.org/10.30752/nj.77168

Aвstract - The Hebrew term kosher means 'fit' or 'proper' and it traditionally signifies foods that conform to Jewish dietary law (kashrut). This article explores how kosher is understood, practised and contested in contemporary Denmark. In recent years, the rules regulating kosher consumption have been supplemented by elaborate rules concerning globalised mass production, which have had an impact on the way people handle questions of kashrut. During the same period, global markets for kosher have proliferated; this article explores the everyday kosher consumption among Jews in Denmark in the light of these transformations. Everyday kosher consumption among a minority group such as Jews in Denmark is not well understood, and I argue that globalised forms of regulation increasingly condition this type of consumption. Even though Denmark is a small and relatively secular country and Jews comprise only about 7,00o individuals, kosher production and regulation have national economic significance. Methodologically, I build on ethnographic data from contemporary Denmark, that is, participant observation and interviews.

\section{Introduction}

This article explores the everyday kosher consumption among Jews in Denmark in the context of the globalised mass production and regulation of kosher products that have taken place over the last couple of decades or so. Kosher consumption of Jews in Denmark is not well understood, and I argue that globalised forms of kosher regulation impact the way people handle kashrut. I understand globalised forms of kosher regulation in relation to the way in which five transnational kosher certification agencies - Orthodox Union (OU), OK Kosher Certification (OK), Kosher Certification and Supervision (KOF-K), Star-K (Kosher Certification) and Chicago Rabbinical Council (CRC) - have been dominant in the global kosher market since the I990s. The research question here is how do Jerws in Denmark practise everyday kosher consumption in light of increasingly globalised forms of regulation? This article forms part of a larger research project that compares kosher and halal (in Arabic literally 'lawful' or 'permitted' in Islam) in Denmark and the UK.

The methodology of this study is based on participant observation and interviews undertaken in 2015-16 with religious organisations/ schools, companies/shops/restaurants and most importantly with Jewish middle-class consumers. This included fieldwork in eight Jewish households (five of which have been included here) in and around Copenhagen. These were selected to obtain a good representative spread within the middle-class segment 
in terms of age, gender and social differentiation more broadly. My research strategy and methodologies allowed me to explore how kosher is understood, practised and contested by producers, traders, regulators and consumers in contemporary Denmark.

Following this introduction, modern kosher principles and practices are discussed. Then the paper engages with theories about transnational governmentality and food practices that help explain how the Big Five and smaller certifiers govern global kosher regulation and the impact this has on Jewish food practices. The second part of the paper is ethnographic; it is introduced by a historical discussion of kosher in Denmark. The next section explores kosher practices among the Jews of Denmark. The conclusion ties the findings of the article together and reflects on the emergence of millennial kosher capitalism.

\section{What is kosher?}

Kosher law is ultimately the application of a system of religious precepts and beliefs that govern the types of foods that people of the Jewish faith eat. This system is based on a number of verses found in the Bible, rabbinic biblical exegesis, ordinances as presented in the Talmud (the written record of the oral law as redacted in the sixth to seventh centuries), and the writings and decisions of later rabbinic authorities. Kashrut is integral to Jewish religious law (balacha) and includes a number of prohibitions such as a ban on pork, the mixing of milk and meat and a prescribed method of slaughter. Meat only qualifies as kosher if the animal is slaughtered using appropriate shechita methods as interpreted through rabbinic commentaries and customary practices. It is central to this process that the blood is drained as fully as possible. Most Jews only consider meat from unstunned animals to be kosher. Moreover, fish must have fins and scales. Central concepts in kosher laws are related to acceptable plants and species of animals. Thus, kosher signifies the classification of permissible and prohibited foodstuffs with a special focus on meat.

The term kosher is also widely used to designate the 'rabbinic properness' of food production, regulation and consumption (Ivry 20I0: 662). In globalised and industrialised mass production of food and food ingredients, considerable effort goes into avoiding any cross-contamination or mixing kosher and non-kosher ingredients (Fischer 20I8). As we shall see, standardisation plays an important role in these processes. Even though global kosher production has been regulated since the I990s, the need for Jewish oversight or 'handling' remains essential and inspections by rabbis show that principles and practices only become compatible during inspections. In kashrut, contamination, transport and traceability (for a product to be kosher all ingredients must also be traceable as kosher throughout the supply chain) have been important issues that require supervision. In the everyday lives of fastidious Jews, it is also important to have separate sets of utensils for milk and meat. At Passover or Pesach, a major Jewish festival that commemorates the exodus from Egypt, special rules apply, as we shall see in the ethnographic section below.

From the I990s onwards the Big Five kosher certification agencies have largely dominated the global kosher market. Important issues in the literature on kosher concern how regulation in the form of certification, legislation and inspections was tightened as a response to increased consumer awareness among Jewish groups on a global scale. The proliferation of kosher production meant that it was no longer exclusively Jews who were in charge of production and this strengthened the need for regulation by trustworthy certifying bodies.

\section{Standardised practices}

Busch (2000) argues that standards are part of the moral economy of the modern world that 
set norms for behaviour and create uniformity. This point is important for the emergence and expansion of global and moral kosher markets. The concept of transnational governmentality (Ferguson and Gupta 2002) elucidates how new practices of government and new forms of 'grassroots' politics are being established on a global scale. Examples include new strategies of discipline and regulation, exemplified by kosher regulation and standards, but also transnational alliances forged by activists and grassroots organisations and the proliferation of voluntary organisations supported by complex networks of international and transnational funding and personnel. The outsourcing of the functions of the state to NGOs and other ostensibly non-state agencies is a key feature, not only of the operation of national states, but also of an emerging system of transnational governmentality. These political entities are integral parts of a transnational apparatus of governmentality. It is necessary to treat state and non-state governmentality within a common frame and as an ethnographic problem.

Warde (2016) observes that agribusiness, sustained economic growth, multinational companies and ever greater international trade have not only transformed the economic foundations of Western diets, but also created possibilities of eating in much more varied ways. In short, food systems experience the effects of globalisation, which is essential in understanding contemporary kosher practices. Drawing on practice-theoretical approaches, Warde sees eating as a type of cultural consumption inseparable from aesthetics and everyday life. Most importantly, perhaps, I am inspired by the term 'compound practice' that captures the complexity of eating in the intersections between different levels of the social scale. Compound practices are shaped by the sharing of practices among family members, for example, and are subject to 'pressures' from other areas - for example, 'health' and 'spirituality'. Moreover, food practices condition and are themselves conditioned by the learning of new tastes, handbooks and manuals on eating and cultural intermediaries, as well as controversies in popular judgements and justification. In contemporary secular Europe significant religious observance coexists with a proliferation of well-advertised specialised diets, that is, it is a feature of the modern world that many options associated with religious conviction, health concerns, political commitment and aesthetic consideration coexist and overlap.

In this sense kosher consumption encompass issues such as 'nutrition' and 'spirituality' (Coveney 2000). For modern consumers, 'nutrition' functions as both a scientific and a spiritual/ethical discipline. It serves this dual function by providing a range of scientific knowledge about food and the body as 'spiritual' disciplines: spiritual here not only means theological, but also refers to the means by which individuals are required to construct themselves with a 'correct' concern for the 'proper' way of behaving in relation to eating. Food practices are subject to direction, coordination and regulation by different (secular/religious) stakeholders and texts that are dedicated to describing and prescribing proper eating practices. Contemporary and historical social environments, institutions and organisations thus condition compound eating practices in Denmark.

\section{Kosher in context}

The Evangelical-Lutheran Church of Denmark is the dominant church/religion in the country, but even so Denmark is characterised by religious diversity. Arguably the room for accommodating religious diversity in Denmark is premised on a particular configuration of secularity dominated by the statesupported Evangelical-Lutheran church. Most 
important, however, is the widely held and strongly embedded popular perception that the public sphere is strictly secular, while Denmark stands out as being highly secular and highly non-secular at the same time, that is, state and church are tightly intertwined (Nielsen 20I4). Ethnic Danes are less likely to favour an active accommodation of religious diversity because they consider themselves to be highly secular - they consider religion to be a private matter that should not be explicitly or publicly accommodated beyond the legal right to practise one's religion (Nielsen 2014). In effect, this means that issues relating to Judaism and Islam such as religious slaughter or circumcision are hotly debated topics. While halal has a strong public presence in urban public spaces such as the neighbourhood Nørrebro in Copenhagen this is not the case with kosher. In general, pork and shellfish are integrated parts of the diet among ethnic Danes.

Jewish migration to Denmark started in the I7oos and today there are about 7,000 Jews in Denmark (Ahlin et al. 20I2: 4IO). The mainstream Jewish organisation in Denmark is Det Jødiske Samfund (The Jewish Community) that maintains a synagogue in central Copenhagen. The Jewish Community has about 2,400 members and a chief rabbi (Borup and Fibiger 2015: 57 ) and it is the central organisation involved in kosher supervision in Denmark.

Orthodox Judaism is by no means extinct in Denmark and since 1996 Chabad, an orthodox Jewish Hasidic movement, has been established in Copenhagen. Chabad is a Hasidic revival movement based in Brooklyn with a focus on the study of religious texts as well as an emotional experience of the divine. The organisation sponsors an international network of religious centres to promote religious observance among Jews. Chabad is often considered highly controversial within Judaism because of the claim of some of its adherents that the late rebbe Menahem Schneersohn was the
Messiah. Rabbi Yitzi and Rochel Loewenthal are Chabad emissaries in Copenhagen. Chabad arranges Torah study sessions as well as Kabbalah and kosher cooking classes and Yitzi expounds the importance of a particular consciousness of one's connection with the divine (Buckser 2003; 2005).

The majority of sources on Judaism in Denmark are Danish and they focus on the earlier history of Danish Jews and their migration to Denmark (Bamberger I983; Blum I973; Blüdnikov I986; Jørgensen I984). Very little is written about keeping kosher in Denmark and there are virtually no academic sources on the significant transformation of the kosher market within the last couple of decades or so. The standard work on modern Judaism and kosher in Denmark is Andrew Buckser's After the Rescue: Jewish Identity and Community in Denmark (2003; see also Buckser 1999; 2005). The Jewish community of Denmark is characterised by institutional integrity as the community has a long history of integration in the country and the synagogue in central Copenhagen is a natural gathering point. However, fragmentation among its members is also visible, that is, disagreement about boundaries of the community, ritual practice and operation of Jewish institutions or kosher practice (Buckser 2003). The religious authority of rabbis in Copenhagen is now challenged by global influences (Buckser 2003: 53) and it is in this context that kosher understanding and practice should be seen. For example, kosher certification by the Big Five competes with that of the Danish rabbinate.

Buckser (2003: 2I-5I) identifies six periods in the history of Danish Jewry. Early settlement (I673-I784); reforms (I784-I8I4) transforming Danish Jews into regular citizens; integration, assimilation and Eastern European immigration (I8I4-I9OI); and immigration, opposition and schism (1900-40) embodied tensions between conservative and liberal factions and 
the continued inflow of Eastern European migrants. Occupation, exile and return (I9405) was a critical period in the history of the Danish Jews. Under the Nazi occupation of Denmark, the protection, rescue and return of Jews changed their role in Danish society and culture. The Danish government refused to take measures against Jews and in 1943 Danish resistance to the occupation turned increasingly violent and the relationship between Danish and German authorities deteriorated. That year the government resigned and plans for a roundup and deportation of Danish Jews started, but the Jews were warned and found refuge in Danish homes and institutions before most of the Jews were ferried to neutral Sweden in fishing boats. Over 95 per cent of Danish Jews survived and this cemented their relationship with Danish society. The period after the rescue, 1945-2000, was dominated

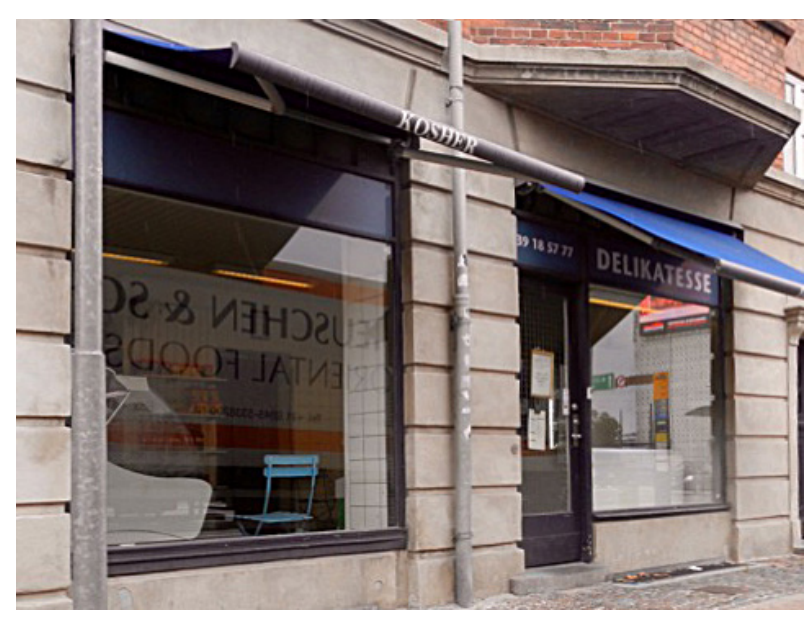

Fig. 1. Copenhagen Kosher chief rabbi from 1996 to 20I4. Kosher products at Copenhagen Kosher (Figure I) carried his seal of approval. Lexner studied to become a rabbi as well as a shochet, that is, a qualified Jewish slaughterer. In addition to his kosher supervision duties in his capacity as chief rabbi, Lexner also helped design kosher kitchens and performed kosher authorisations in private homes - he was the main authority on kosher in Denmark. For twenty years Rabbi Lexner worked as a shochet in Denmark. As a chief rabbi, he was solely responsible for 'national' kosher certification in Denmark under the auspices of the Jewish Community in Denmark. Lexner was involved in making a kosher list for Jews in Denmark: a guide to kosher living for everyday consumption. The present rabbi, Melchior (see below), developed this list further; it can be found on the website of the Jewish Community in Denmark by a polarisation between liberal and conservative wings of the congregation as Jews entered mainstream society. Generally, many Jews seem to associate religiosity with the irrational while admiring the authenticity of very religious groups (Buckser 2003: 50). My empirical exploration of kosher focuses on the two most important organisations involved in kosher supervision in contemporary Denmark, the Jewish Community and Chabad.

Because the Jewish community is rather small in Denmark a handful of people have played important roles in Jewish organisations. In the Jewish Community Bent Lexner was the
( <http: / / w w w.mosaiske.dk / guide-to-keeping-kosher-in-denmark $>$ ).

Rabbi Lexner concedes that Chabad is stricter about kosher in that they only eat what is produced under supervision by a recognised kosher certification body. Another difference is that Chabad and its rabbi works as a kosher supervisor for the kosher certifier Circle K. This is different from the chief rabbi's own work, in which he personally lends his name to kosher products and their certification. So, in order to supervise and certify what is kosher in Denmark, the chief rabbi has people who supervise for him. 
Rabbi Lexner explains that his involvement was not about 'big business' and profits alone. Instead, for example, he advised companies on how to acquire OU certification, and checked papers on trucks from abroad to ensure traceability. The Big Five, the biggest kosher certifiers globally, have gradually increased their influence vis-à-vis local or national forms of certification, such as that of the Danish rabbinate, for example. Some companies in Denmark that export kosher products are fine with national certification, whereas others turn to Circle K and other Big Five certifiers that they believe can give them an edge in the global market. Lexner recalls that for a long time Israel only accepted national forms of certification by a chief rabbi, but that has changed and today the Big Five are more widely accepted.

Rabbi Jair Melchior is in his thirties; he became the chief rabbi in 2014, taking over from Bent Lexner. Regarding kashrut, his responsibilities include, firstly, informing and updating the congregation on what they can and cannot eat - especially in a globalised world when many different opinions, rabbinical and otherwise, circulate. More specifically, Rabbi Melchior's role is to create a national Danish opinion or ruling on the 'kosherness' of products consumed by Jews in Denmark amidst other opinions from Big Five rabbis and other discourses found on the internet. Being a relatively small country with a limited number of Jews actually necessitates thorough and systematic rabbinical supervision because kosher products are hard to come by: this means that many Jewish consumers will buy their products in ordinary shops or over the internet; this warrants rabbinical supervision and opinions.

Secondly, Rabbi Melchior's work focuses on supervision and certification of Danish products exported to major markets such as Israel, the US or the UK. In this respect he carries out inspections and checks the "kosherness' of ingredients and the validity of certificates. In the filing cabinet in Rabbi Melchior's office there are many files on companies he is responsible for supervising. Normally, he sends members of the congregation to do supervision tasks in these companies - especially when a new company wants to be certified: a company may start manufacturing a new product or change its ingredients. Generally, certified companies receive one yearly visit form Danish rabbinic representatives.

When discussing changes in supervision processes since Rabbi Melchior took over from Bent Lexner, he explains that such processes are increasingly being formalised: today, a contract is drawn up whereas previously supervision was mainly based on oral agreements; this creates 'increased transparency' locally as well as internationally. Rabbi Melchior also supervises Copenhagen Kosher; because most products are imported and thus carry recognised kosher logos this is uncomplicated. More effort goes into supervising the in-shop manufacturing of sausages with raw materials such as spices that are not certified, for example. It is complicated and expensive to find kosher certified spices, so this type of ingredient calls for a rabbinical opinion.

Rabbi Melchior uses several sources of knowledge when checking products and ingredients: the internet as well as rabbinical contacts with London Beth Din, the rabbinate of Israel and the chief rabbi in Berlin. As a global player, OU supervises and certifies over 500,000 products, and Rabbi Melchior recognises that many companies prefer this kind of global and costly supervision - comparing the cost of supervision/certification by the Danish rabbinate and OU, the latter seems around four to five times as expensive. Moreover, there is also a 'political' aspect to the relationship between supervision by the Danish rabbinate and global forms represented 
by the Big Five. The difference between the Danish rabbinate and Chabad supervision is that Chabad does supervision for Circle $\mathrm{K}$ and not independently.

In the eyes of Rabbi Loewenthal and Chabad, keeping kashrut is a religious obligation for religious Jews, even in a 'secular' Danish context where religious observance is declining. He explains that today in Denmark people make their own standards and that they are not so strict. Thus, not only does kosher have 'a rougher time' in secular Denmark, but the only kosher shop, Copenhagen Kosher, has limited opening hours and the products are more expensive; keeping kosher thus requires more effort physically, mentally and financially in comparison to the UK or US, for example. Previously even 'cultural Jews' tended to keep kosher, Rabbi Loewenthal argues.

Rabbi Loewenthal is involved in the certification of several foodstuffs manufactured in Denmark that are exported to the international markets, mainly Israel and the US. While science is important for testing products for pork DNA, for instance, he argues that laboratory testing alone is often insufficient: 'kosherness' hinges on a combination of factors - proper integration of religious laws with modern food science, technologies at the cutting edge of food science and applying and adapting ancient rules to a modern situation. Questions like what's a freeze drier and how does it work? and when does equipment need kosherising? are essential in order to understand the ways in which products are manufactured and the information companies provide themselves.

In Denmark, kosher slaughter was banned in 2014 because stunning the animal before slaughter was now required by law. This decision follows previous debates in Denmark about religious slaughter and the marking of slaughtered meat, and it stirred up deep controversy among Jewish and Muslim groups both within the country and beyond. It is in this context that the empirical data below should be seen. Even if the market for kosher products has shrunk over the years as the number of Jews has declined, the above discussion shows that Denmark is fully integrated into the global market for kosher that has developed from the I99os onwards. For example, the world's largest producer of enzymes, Novozymes, is based in Denmark and the company is certified by the leading global kosher certifier, the Orthodox Union. Kosher biotechnical production is subject to elaborate rules that have warranted regulation over the last two decades (Fischer 2018). Thus, kosher regulation in Denmark is not only about local consumption, but also about exports to global markets, in which the Big Five play important roles.

\section{Keeping kosher or not keeping kosher?}

In this section I explore how Jewish consumers in Denmark understand and practise kosher consumption in their everyday lives. Dietary practices provide a common symbolic system through which the increasingly heterogeneous notions of Jewish identity in Denmark can be expressed and one way to reinforce one's Jewish identity is by keeping kosher (Buckser 1999). Similar studies exist for Canada (Diamond 2002) and Brazil (Klein 20I2) and it is this literature that this study feeds into. As in these studies, my Jewish informants are urban middle-class individuals who are socially mobile: well-educated and relatively affluent. This focus on social class is important because within this group informants try to balance piety and health concerns and at the same time these Jews can afford the high prices in Copenhagen Kosher, for example. I do not claim that my ethnography and informants are representative of the entire Jewish community in Denmark; my informants were selected to obtain a good representative spread within the urban, middle-class social group in terms of age, gender and social 
differentiation more broadly. This empirical data below are organised so that I start out by discussing consumers who are very observant about kosher and then gradually I move towards more non-observant or relaxed consumers at the other end of the spectrum.

Naomi is a woman in her mid-fifties who lives with her husband near Copenhagen. She has a son and a daughter, and she is currently self-employed. Naomi grew up in Israel and moved to Denmark in the early I980s when she married her first husband. Naomi recalls that as a child her grandmother would stress that a contaminated teaspoon should be buried in the garden in order to kosherise it. She believes that the material world, including food and drink, is symbolic in that it represents something bigger and more spiritual. She is a vegetarian and this fact makes her everyday food consumption in Denmark easier. Naomi thus says a blessing before consuming food and drink, acknowledging that these practices are just as much about spirituality as they are about everyday nutrition, and a thanking prayer after consuming a certain amount of food or drink. With specific reference to kosher, Naomi considers herself orthodox and fastidious, but not 'extreme', arguing that she accepts many types of kosher logos and that this would not be the case for ultra-orthodox individuals and groups. Most of all, Naomi recognises kosher certification by Badatz (a major Jewish rabbinical court).

At the age of twelve, Naomi started to identify with her grandmother's family and to keep kosher stringently. This posed a challenge for her mother, who 'expressed love and affection through food'. The family purchased glass plates with hard and impenetrable surfaces, and which, according to some, may be used for both meat and dairy products. She kept the kosher rules to the best of her ability, waiting six hours after eating meat before consuming dairy products. Five years ago, she started studying the Kabbalah (Jewish spirituality and cosmology).After six months she realised that these studies are meaningless without physical practice. Keeping kosher in the Danish context was reinforced by a stress on Jewish culture, religion and consciousness. Yitzi Loewenthal, the Chabad rabbi, helped Naomi set up her kosher kitchens (located on separate floors in her house): one is for milk cooking and the other for meat. These two kitchens also have separate sets of utensils. More generally, Naomi consults her son or the internet if she is in doubt about products and ingredients.

Naomi explains that in her everyday shopping for food in Denmark certain skills are essential. Most of all she looks for proper kosher logos such as that of Circle $\mathrm{K}$ on chocolate as well as other available products. Moreover, there is a list of approved products and ingredients issued by the Jewish Community in Denmark. In addition to this list, which Naomi does not always agree with, she uses apps and Google to find specific products and ingredients on other lists around the world. Again, being a vegetarian makes this process easier. There are few kosher logos to be found in shops in Denmark so Naomi looks for e-numbers (codes for permitted substances within the EU) that can tell her about the acceptability of products. She explains that in Judaism insects are considered to be even more problematic than pork. Hence, Er2o (a colouring agent called carmine extracted from an insect sitting on cactus in Mexico that adds a ruby-red colour to drinks, for example) is completely unacceptable. Occasionally, she will go to the Kosher Delicatessen \& Deli in Copenhagen to buy things like chewing gum and Mentos, but also to support the business.

She refers to the dogma bishul akum (food cooked by a non-Jew) when arguing that in general observant Jews are not allowed to consume food prepared by non-Jews. Because 
wine and grape juice have a ritual status in Judaism she is careful when buying it and does so either in Copenhagen Kosher or at the website <http://www.kosher4u.eu>, where a wide variety of kosher products are available at reasonable prices. This is also where she buys grape juice and bread for Pesach or Passover. Even as a vegetarian she feels that ritual slaughter is acceptable and that it is more humane than industrially slaughtered stunned meat.

In terms of home cooking, Naomi, like most other Orthodox Jewish women, she argues, is responsible for shopping and cooking. More generally, every new kitchen item must have a hard surface and if a non-Jew produces it it must be kosherised. This is done in a mikve (a bath used for the purpose of ritual immersion in Judaism). Naomi does not really go out to eat or drink in restaurants because there are no kosher eateries in Denmark. When visiting Jewish friends and family, she accepts the food when she's reassured about their knowledge of keeping kosher.

Naomi believes that keeping kosher is healthier spiritually and for your body: for example, she states that drinking milk separately from and before meat lowers the risk of colon cancer. She believes that some products manufactured by Muslims are acceptable, especially when kosher is unavailable, but states that such products must be controlled and must not contain meat or milk.

Hanne and Niels are a couple in their mid-sixties who live in a flat in Copenhagen. They have three children in the US and Israel. Niels was educated in civil engineering and Hanne as a pharmacist. They keep kosher as much as they can based on their knowledge and have done so since childhood. Niels explains that you either keep kosher or you don't - there's no easy option. The couple go about their everyday shopping for food in several shops, including the kosher delicatessen, and also at supermarkets, where they look carefully at labels. Niels feels that it is helpful that proper labels are statutory in Denmark and can easily be checked and that 'there's no excuse for not keeping kosher'. In particular the couple looks for animal contents and potential new ingredients and they also consult the list of approved products issued by the Jewish Community in Denmark, even though it is not always updated. Hanne is lactose-intolerant and this makes her more alert when shopping for food and drinks. The couple recalls an incident in a local supermarket when they looked at the label of a wine produced in South America and were surprised to find that it contained milk, which also surprised the rabbi they consulted. Generally, as long as the Jewish Community rabbi approves e-numbers, the couple relies on this decision.

Meat and cheese are only bought at the local delicatessen; they explain that their children in the US and Israel have an easier time shopping for meat in markets with much better availability compared to Denmark. However, they bring cheese back from the US or Israel when visiting their children. They also accept the cream cheese Philadelphia that is produced using microbial technology and not rennet (a complex of enzymes).

All available kosher logos are accepted in the delicatessen and the couple do not prefer particular logos to others; they have no issues with vegetables as long as they are washed thoroughly. At Passover 'everything' is bought at the delicatessen even if prices are higher here. Because of relatively high prices and the availability of kosher their meat consumption is limited: meat is mostly eaten at weekends and when guests come over. It is mostly Hanne who shops and cooks, but they both possess knowledge of e-numbers, for example, that can also be looked up on smartphones over the internet. In general, the couple explain that 
they rely on the judgement of the rabbi of the Jewish Community as well as experiences of other Jews in Denmark.

They feel that it would be convenient to have more kosher availability in Denmark - for example frozen foods at the nearby supermarket. Even if halal products are widely available in nearby shops these in no way present an alternative to kosher: Niels argues that generally 'the kosher slaughter is halal, but not the other way around'.

Both Niels and Hanne think that keeping kosher is met with understanding in Denmark - for example, when Hanne is meeting up with her old schoolmates the menu is sent to her beforehand and she is always offered fish. In their workplaces kosher dietary requirements are also taken into consideration. Going out to restaurants is far more complex and when they do go out to eat, they usually have boiled fish, as Niels explains: 'We would not accept barbecued fish because you never know what's been on the grill before'. However, they do accept the eating utensils when they go out to eat, and Hanne explains that if they did not 'they could never go out'. In their kosher kitchen there are five sets of utensils: one for guests; a pair of sets for milk and meat respectively and an identical pair for Passover. Jokingly, Niels explains that installing two dishwashers was confusing to the plumber.

When discussing whether keeping kosher is healthier the couple make the case that they keep kosher out of belief and not because of health concerns. However, they feel that kosher may actually be healthier and that this point has been backed up by scientific evidence recently. Niels says: 'I'm not sure whether this is based on facts or not [...] At sports competitions in hot climates athletes do not eat molluscs such as snails or shrimps to avoid the danger of food poisoning.'

With regard to the relationship between food and non-food products, the couple has one washing-up brush for milk, one for meat and one for Parve (neither milk nor meat). All brushes should have nylon brushes and not bristles of animal origin. Similarly, hand soap without any animal ingredients is used. At Passover, kosher toothpaste is brought home from the US or Israel when visiting children because this toothpaste is not available in Denmark. However, when we discuss the necessity of San Pellegrino Soda being kosher Niels and Hanne agree that this is not really necessary. They speculate that if living in the UK, for example, they would probably accept and thus buy a wider variety of kosher products - also because prices are generally lower in the UK. They are familiar with the UK kosher market because Niels's sister lives there.

The couple point out that very small quantities of unknown substances are generally seen to be acceptable; but Niels also states that when it comes to medication gelatine is not essential. When we discuss the limited nature of the kosher market in Denmark compared to huge and growing global market, Niels is quite knowledgeable, as he once conducted kosher supervision for one of the major Danish multinational companies.

Rosa is a woman in her forties who works in a private company. She has a non-Jewish husband and two children who attend the Jewish school. Rosa moved to Denmark seventeen years ago from Eastern Europe and describes herself as a 'convenience Jew', that is, in the eyes of Rosa 'kosher is an individual and flexible choice' mainly focused on pork avoidance. Having children at school increased the family's focus on 'kosher life'. Her son takes kosher seriously and strictly avoids pork, and for this reason Rosa stopped eating shrimp and mussels herself - she knew this was important for her son and she respects his preferences. However, ritual slaughter and the question of stunning is not important to 
the family. Thus, Rosa to a large extent experiences 'kosher living', and the fact that this is expensive in Denmark, through her children. Moreover, because of their special preferences the children will bring their own food, including meat, to Carolineskolen, a Jewish school at the outskirts of Copenhagen, that only offers a vegetarian diet.

Rosa recalls a conversation with a Jewish friend that puts her own kosher priorities into perspective: the friend told her that her son wanted to taste pork and that she was strongly opposed to this. However, being a 'convenience Jew' Rosa did not impose her views and fully accepts that everybody should follow their own path without dogmatism: choosing 'super-orthodox kosher living' can only apply to oneself; others must find their own way. In Denmark she states that most Jews are flexible, while a smaller group prefers 'kosher for ever', which can be a complex choice in the Danish context: kosher is expensive, hard to come by and kitchens and fridges are not designed for kosher, for example. When her son's strict friend visits their home, food is served on a paper plate and the friend enquires about 'what's in this or that dish' or 'what's been in the oven before?'

Even though Rosa sees herself as a 'convenience Jew', the idea of supporting Israel through shopping or consumption appeals to her. For example, once she noticed Jaffa oranges in a shop and she felt that it was natural to buy these in support of Israel, even if this is not a consistent choice in her everyday life. Rosa's flexibility with regard to kosher is also apparent in that she often goes to particular supermarkets to buy organic and non-kosher meat - it is virtually impossible to find organic kosher meat in Denmark and she also goes to halal butchers if these have been recommended by Muslim friends. In general, Rosa prefers organic produce over kosher. Rosa recognises that there are many similarities between kosher and halal and the family also accepts halal sweets if they can find them. This flexibility also means that she does not really think that being a Jewish consumer in Denmark requires particular skills.

More generally, Rosa explains that the majority of the Jewish community has been 'assimilated'. If Jews in Denmark send their children to the Jewish school, she argues, you are part of that community even if you do not go to the synagogue or the Chabad house. Rosa once attended a kosher cooking class at the Chabad house, which she found really interesting. The course, taught by Rochel Loewenthal, gave her an insight into the 'kosher lives' of others and refamiliarised her with Jewish dishes such as chicken soup. Even though Chabad represents dogmatic and ultra-orthodox Hasidism for Rosa, taking the cooking class made sense.

If the family wants to buy specific kosher products such as wine gums that are not available in ordinary shops, the brand Goody Good Stuff can be bought at 7-II; for products that are unavailable in Denmark they use <http:// www.www.kosher4u.eu>. In general, shopping and cooking is divided between Rosa and her husband. If the family has a celebration Rosa or her husband will ask Jewish guests about specific food preferences beforehand, but she will cook fish at these occasions rather than buy kosher meat at the delicatessen. Being flexible about kosher also allows the family to go to restaurants in Denmark; Rosa explains that if she was stricter about kosher, she could not do the job she does, which involves extensive travel - often on the Sabbath.

Rosa believes that separating milk and meat makes kosher healthier and that this is a principle that applies to diets in general: protein and milk should be separated as they naturally represent separate chemical processes, yet she states this does not apply to eating steak and cheese together. Rosa does 
think kosher enzyme certification is significant as all ingredients must comply with kosher rules, and the same goes for non-food products such as leather that may come from pigs.

Rafi is a man in his thirties who has lived in Denmark for thirteen years and now works in IT. He moved to Denmark from Israel, where he met his non-Jewish Danish wife in a kibbutz. Rafi explains that he is not very fastidious about kosher as he grew up in a secular family. Traditionally, Rafi's family would be flexible about their religion and they would go to the synagogue, light candles and avoid work at religious festivals, but accept watching TV during the weekend, for example. Rafi's family keeps kosher and when his mother visits the family in Denmark Rafi is more focused on kosher and goes to the delicatessen or serves fish/vegetarian dishes.

When Rafi was a teenager, he would eat cheeseburgers, but to this day 'When I see a colleague of mine eat a burger with a glass of milk it seems strange. I can eat a cheeseburger, but drinking milk and eating meat is strange.' Thus, even if Rafi sees himself as a flexible Jew the overt mixing of milk and meat that is so common in Denmark is unfamiliar. With regard to meat the family prefers beef, but occasionally pork is also eaten. The situation in Denmark is radically different from Israel: when Rafi was in the army everything was kosher, an approach to kosher that he sees as dogmatic and representative of unwelcome orthodoxy. As a teenager he started breaking kosher rules, for example eating cheeseburgers, to rebel against his father. Rafi's own children 'eat what they are served', but at the Jewish school they keep kosher. His daughter wanted to keep kosher at home after a couple of years at school, but regretted this decision when realising that she then could not have spaghetti carbonara. In general, Rafi feels that too many groups within Judaism take kosher to extremes. Orthodox rabbis reinforce dated traditions to claim authority in a way that was never intended. Kosher enzymes are an example of this in Rafi's eyes. Religious orthodoxy and over-interpretation infuse the market and regulation of kosher rather than common sense. To Rafi, what makes sense in Judaism is a form of cultural heritage created over generations; kosher rules may have made sense historically when there were no fridges, but not today they seem dated and unnecessary.

When we discuss whether kosher is healthier or not Rafi argues that many Danes regularly eat pork so that it must be limited how harmful to health pork actually is. In the eyes of Rafi, it makes sense that kosher is regulated to avoid horsemeat or sick animals, and kosher may therefore be considered healthier. Conversely, he does not consider the separation of milk and meat healthier and the same goes for avoiding shellfish, but he would not eat shrimp in Israel in August.

The family mostly goes about their everyday shopping in supermarkets and although they live close to the delicatessen Rafi only goes there when his mother or observant Jews are visiting: personally, Rafi prefers meat that is fresh and not frozen and expensive, as is the case in the delicatessen. In the case of oranges and avocados Rafi would buy those produced in Israel to support local produce, but he does not support kohser in the same way.

The family does not have a kosher kitchen; this becomes particularly problematic when celebrating children's birthdays and when Orthodox guests visit, for example. Rafi stresses that this is an occasion when he makes sure that all guests are treated well and that visiting children do not have to bring their own food. Thus, he would go to Chabad to bake kosher rolls, only use kosher butter and serve everything on paper plates. For these 
occasions the family have also bought sweets in bulk when visiting relatives in Israel to bring back to Denmark. Rafi's family is flexible about going out to restaurants and at work he has no problems eating the food that is served at the canteen. The family also accepts halal meat and products more generally whereas they think organic products are too expensive.

Hagai was born in Israel, grew up in a Kibbutz and has now lived with his Danish wife and three children in Denmark for six years. Now in his thirties, he was educated as a cook and is currently pursuing further studies in Copenhagen. Although Hagai sees himself as 'ultra-secular' like his parents, and kosher has 'absolutely no significance' in the family's everyday life, his children attend the Jewish school in Copenhagen. Overall, however, he sees kosher as a kind of unwanted political ideology that should not be allowed to dictate everyday practice, not least because it represents state and religious power, economic gain and manipulation. Hagai's background is influenced by his secular upbringing in Israel and when attending a secular school, he looked for non-kosher foods and pork to protest. In the Israeli army everybody must fit in, so everything is kosher to cater for ultra-orthodox groups, and the same goes for hospitals and schools. It was this system Hagai rebelled against. These institutions are under rabbinate supervision and kosher logos are ubiquitous and thus controlled by authorities that Hagai challenges. Most of Hagai's friends are likeminded, but he does have some friends who are more Orthodox. In his children's school several of the other children are far more fastidious about kosher, which can be challenging. Some Jewish families in Denmark keep kosher at home while being flexible in public, but others are also observant in public - celebrating a child's birthday, for example, is an event where kosher becomes important in order to accommodate all guests. In this instance, Hagai goes to the delicatessen to make sure he can cater for the more Orthodox guests. Another challenge is when socialising with Orthodox friends or family in Israel that focus on the separation of milk and meat and pork avoidance.

Hagai's family basically eats 'anything', but avoids pork because of animal cruelty. They are far more focused on buying organic and wholesome products. Another aspect of the family's food preferences is to cook typical Danish dishes such as pork meatballs (frikadeller) as well as falafel, humus and tahini that represent Israeli and Middle Eastern cuisine. To Hagai it is important that his children learn about these two food cultures. He explains that he does not believe that kosher is healthier in any way, but that kosher has a different taste because it is salted and dried. He believes that there are many similarities between kosher and halal and the family has no problem buying halal meat. Regarding meat, the main principle is the taste and quality on the one hand and making sure that no animal cruelty is involved in producing the meat on the other.

\section{Discussion}

It soon becomes clear that all these middleclass consumers are acutely aware that they are living in a world where kosher markets are globalising. Even the most 'secular' of these consumers must relate to and negotiate larger issues - kosher as formative of distinctions between individuals and groups in everyday life; the specific national and local contexts that frame their lives and 'kosher globalisation', including how transnational governmentality frames their everyday choices and how they must practise more self-discipline in deciding what is and is not acceptable. There is limited and shrinking kosher availability in Denmark. Meat remains at the centre of kosher understanding and practice. While there are differences in levels of observance, all Orthodox informants argue that stunning 
animals before slaughter is unacceptable. In the Danish context the Jewish population is small and shrinking; this is also reflected in the market. More specifically, the small size of the Jewish community and the fact that there is only one kosher shop in the entire country frames the everyday understanding and practice of kosher in Denmark: kosher meat is hard to come by and expensive. That said, all informants are acutely aware that the global market for kosher is huge and expanding on the one hand and on the other that certification by the Big Five is a global and lucrative business. This is good news for the more Orthodox groups, who value increased regulation, while more relaxed groups find this excessive and unnecessary.

Among the most Orthodox informants, kosher is conditioned by using a mikve or setting up a kosher kitchen. Conversely, more secular informants either describe themselves as 'convenience Jews' or being ideologically against kosher as an expression of a dogmatic and capitalist, and thus unwanted, form of religion. However, more relaxed Jews also send their children to the Jewish school, where vegetarian kosher food is served, and many explain that to a large extent kosher is only about only their own preferences and those of their family. Several informants who are either relaxed about or explicitly critical of kosher explain that at children's birthdays, for example, they go to the kosher shop or consult Chabad in order to make sure that children from more Orthodox families feel welcome. Many informants rely on a kosher list published by the Jewish Community in Denmark, covering acceptable foods, while others consult Chabad or look up products/ingredients on the internet. Quite a number of the children from more Orthodox families have moved to Israel, the US or the UK - and much of the meat imported into Denmark comes from the UK. Several informants also explain that they bring meat back from these countries by themselves, their children or friends. Because the kosher market is so limited in Denmark all informants go to ordinary stores for their everyday shopping; for the Orthodox group this entails in-depth knowledge of e-numbers, for example. Several informants explain that they are often surprised to see that suddenly a product they have been buying over many years may now contain a new, questionable and often unwanted ingredient. While some informants argue that keeping kosher is healthier, for example avoiding blood and separating milk and meat, it is again clear that judgement about what to do in a given context can be extremely complex. Hanne and Niels make this point well, stating that if they did not use the utensils provided in eating establishments in Denmark they would probably never go out. Thus, kosher knowledge not only defines Jewish group identity in Denmark, but also family and everyday life through compound practice: even the most 'secular' or flexible of my informants are well aware that kosher is economically important in production, trade, regulation and, most importantly, as everyday practice among Orthodox Jews.

Very few of my informants were aware that enzyme production has undergone kosher supervision and certification in recent decades; that said, the majority thought it was a good idea. However, this supports the argument that modern forms of transnational governmentality tend to take on a life of their own: the relationship and cooperation between producers, sellers and certifiers is intensifying to an extent such that most consumers are unaware of these trends and processes. The availability of a wide range of new kinds of foods has exploded in Denmark over the last couple of decades and arguably it will become more difficult for kosher consumers to know what to eat where, even though it is easier to find information than it once was on how to judge 
what is and is not acceptable. I have shown that while some Jewish groups are fastidious about their everyday kosher consumption this is by no means the case among all Jews in Denmark. Fastidiousness has reinforced regulation of global kosher production and regulation and kosher certification and logos are extremely important in the everyday lives of many Jewish groups in Europe. However, many Jewish consumers in Denmark together with local Jewish organisations feel that the Big Five kosher certifiers have become global, commercial and powerful to such an extent that their certification of thousands of companies and products has taken on a life of its own that is detached from the everyday lives of Jewish consumers.

Even if meat is still subjected to the most stringent religious requirements, e-numbers are also a concern to some individuals, who for the most part put a lot of effort into their everyday shopping practices. Some of the observant Jewish informants are focused on non-food products in specific ritual contexts - kosher toothpaste is only of importance during Passover, while toothbrushes and dish brushes should have nylon and not animal bristles. Many observant Jews put a lot of effort into maintaining this ritual separation - even in small Copenhagen kitchens. In Denmark more generally the limited availability of kosher products makes these issues more significant in terms of everyday practice. Some informants are convinced that kosher is not only 'spiritually' but also 'physically' healthier for a range of reasons. In general, they also possess a basic knowledge of the food taboo of the other, that is, Jews tend to know that halal is mainly related to ritual slaughter, as well as to pork and alcohol avoidance.

Contemporary food preference and avoidance also reflect changing social relations between individuals and groups over time, demonstrating how cultural tastes are transformed in line with changes in political power and socio-economic organisation. The empirical material highlights the ways in which 'food piety' is practised in everyday life. Celebrations, religious festivals and eating out are now more complex for kosher and halal consumers for a whole range of reasons, with strategies and forward planning thus becoming more important in a minority religious context. Considered alongside the increasing complexity of food production that has emerged in recent decades, it is clear that kosher consumers in contemporary Western societies often have problems knowing what and where to eat, and that they often require more elaborate forms of justification and self-discipline when deciding what is and is not acceptable. Kosher consumption thus remains central to debates about what religion is or ought to be for Jews in Denmark.

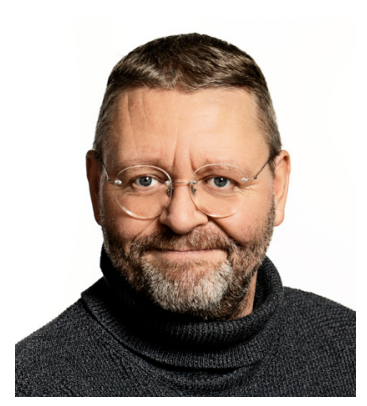

Johan Fischer is Associate Professor in the Department of Social Sciences and Business, Ros ki l d e University, Denmark. His work focuses on modern religion and markets. He is the author of Proper Islamic Consumption: Shopping among the Malays in Modern Malaysia (NIAS Press, 2008), The Halal Frontier: Muslim Consumers in a Globalized Market (Palgrave Macmillan, 2011), Islam, Standards, and Technoscience: In Global Halal Zones (Routledge, 2015), Halal Matters: Islam, Politics and Markets in Global Perspective (Routledge, 2015), Religion, Regulation, Consumption: Globalising Kosher and Halal Markets (Manchester University Press, 2018), Kosher and Halal Business Compliance (Routledge, 2018), Muslim Piety as Economy: Markets, Meaning and Morality in Southeast Asia (Routledge, 2019) as well as articles in journals and edited volumes. 


\section{References}

Ahlin, Lars, et al., 20I2. 'Religious diversity and pluralism: empirical data and theoretical reflections from the Danish Pluralism Project', Journal of Contemporary Religion, 27(3), pp. 403-18.

Bamberger, Ib N., I983, The Viking Jews: A History of the Jerws of Denmark (New York, Shengold Publishers).

Blüdnikov, Bent, 1986. Immigranter. Østeuropaiske Jøder i København 1900-19I7 (København, Borgen).

Blum, Jacques, 1973. Dansk og/eller jøde? En kultursociologisk undersøgelse af den jodiske minoritet i Danmark (København, Gyldendal).

Borup,Jørn, and Marianne Q.Fibiger, 2015. Religion $i$ Danmark (Aarhus University).

Buckser, Andrew, 1999. 'Keeping kosher: eating and social identity among the Jews of Denmark', Ethnology, 38, pp. 191-209.

-2003. After the Rescue: Jewish Identity and Community in Denmark (London, Palgrave Macmillan).

— 2005, 'Chabad in Copenhagen: fundamentalism and modernity in Jewish Denmark', Ethnology, 44(2), pp. I25-45.

Busch, Lawrence, 2000. 'The moral economy of grades and standards', Journal of Rural Studies, I6, pp. $273-83$.
Coveney, John, 200o. Food, Morals and Meaning: The Pleasure and Anxiety of Eating (London, Routledge).

Diamond, Etan, 2002. 'The kosher lifestyle: religious consumerism and suburban orthodox Jews', Journal of Urban History, 28(4), pp. 488-505.

Ferguson, James, and Akhil Gupta, 2002. 'Spatializing states: toward an ethnography of neoliberal governmentality', American Ethnologist, 29(4), pp. 981-1002.

Fischer, Johan, 2018. 'Kosher biotech: between religion, regulation and globalization', Religion and Society: Advances in Research, 9, pp. 52-67.

Ivry, Tsipt, 20Io. 'Kosher medicine and medicalized Halacha: an exploration of triadic relations among Israeli rabbis, doctors, and infertility patients', American Ethnologist, $37(4)$, pp. 662-8o.

Jørgensen, Harald, I984. Indenfor murene: jødisk liv i Danmark r684-I984 (Copenhagen, C. A. Reitzel).

Klein, Misha, 2012. Kosher Feijoada and Other Paradoxes of Jerwish Life in Sao Paulo (Gainesville, University Press of Florida).

Nielsen, Anne M., 20r4. 'Accommodating religious pluralism in Denmark', European Journal of Sociology, 55(2), pp. 245-74.

Warde, Alan, 20I6. The Practice of Eating (Cambridge, Polity Press). 